

e-issn 2175-1803

\title{
Fantasmagoría: imagen de la contradicción en un tiempo suspendido
}

- Paola Helena Acosta Sierra

Doctora en Teoría Crítica por 17, Instituto de Estudios Críticos (México).

Profesora titular de la Universidad Pedagógica Nacional.

Bogotá - COLOMBIA

academia.edu/PaolaHelenaAcostaSierra/CurriculumVitae

paoladesumerced@gmail.com

(1) orcid.org/0000-0003-0134-1571

Para citar este articulo (ABNT):

ACOSTA SIERRA, Paola Helena. Fantasmagoría: imagen de la contradicción en un tiempo suspendido. Tempo e Argumento, Florianópolis, e0 106, 2021. Número especial.

doi http://dx.doi.org/10.5965/21751803ne2021e0106 
Fantasmagoría: imagen de la contradicción en un tiempo suspendido

\title{
Resumen
}

Río Abajo, obra presentada por la artista colombiana Erika Diettes en el 2008, plantea un encuentro con el duelo que enfrentan los familiares de personas desaparecidas que han sido arrojadas a los ríos de Colombia. La obra se compone de una serie de fotografías de prendas de vestir, flotando en agua, que pertenecían a las víctimas, lo que nos sumerge en un mundo plagado de fantasmas reales donde los límites temporales y espaciales que delimitan el mundo de los vivos se distienden y establecen un diálogo doloroso pero necesario en una sociedad que tiende al olvido y al anestesiamiento. Aquí hay una aproximación desde la estética y la filosofía a esta obra, en un lugar - Colombia- donde hablar de los desaparecidos es un acto político.

Palabras clave: Erika Diettes; conflicto armado en Colombia; desaparecidos; historia del tiempo presente; dispositivo estético; fantasmagoría.

\section{Phantasmagoria: image of contradiction in a suspended time}

\begin{abstract}
Río Abajo, a work released by the Colombian artist Erika Diettes in 2008, brings up an encounter with grief faced by the relatives of missing people who have been thrown into the Colombian rivers. The work consists of a series of photographs of clothing, floating in water, which belonged to the victims, immersing us in a world full of real ghosts where the temporal and spatial constraints that delimit the world of the living are stretched and establish a painful but necessary dialogue in a society that tends to forgetfulness and anesthesia. Herein there is an approach from aesthetics and philosophy to this work, in a land -Colombia- where talking about missing people is a political act.
\end{abstract}

Keywords: Erika Diettes; armed conflict in Colombia; missing people; history of the present time; aesthetic device; phantasmagoria.

Empiezas a conocer la realidad. Y empiezas a caer en la cuenta que si el dolor matara, en Colombia no habría gente viva. Erika Diettes (2017. Información oral)

En el año 2008, Erika Diettes estrena en De Santos Gallery', Houston, Texas, Estados Unidos (EE. UU.), su obra titulada Río Abajo, compuesta por 26 fotografías

\footnotetext{
De Santos Gallery, una galería diseñada por el arquitecto Fernando Brave, fue inaugurada en el año 2003. El espacio es propiedad de Luis y Gemma De Santos, nativos españoles y residentes en Houston, EE. UU. De Santos Gallery se ha especializado en situar en sus instalaciones obras fotográficas en todas sus expresiones; aunque destacan a los artistas nacionales, distintos fotógrafos internacionales han expuesto sus obras en esta galería.
} 
de prendas y objetos personales sumergidos en agua, estas ropas - prestadas a la artista por parte de los familiares- les pertenecen a diferentes detenidos desaparecidos del conflicto armado colombiano. La obra se constituye en un escenario de reflexión sobre la labor funeraria de los ríos de Colombia, al entenderlos "como espacio geográfico de evocación de la muerte. La obra también contribuye en el proceso de duelo de las víctimas al recobrar simbólicamente en estas imágenes la presencia de un cuerpo que no han podido encontrar" (DIETTES, 2017?).

En el 2016, Diettes instala Río Abajo en el Museo Rayo² del municipio de Roldanillo del departamento Valle del Cauca, Colombia. Además, la artista lleva la obra a los 18 municipios del nordeste del país en donde se ubicaban los familiares de las víctimas que habían decidido entregarle una prenda o un objeto que representaba a su ser querido detenido desaparecido. Diettes, en una entrevista de una cadena radial colombiana, manifiesta que en el trabajo de campo le entregaron 150 objetos que posteriormente fueron fotografiados; aunque algunas exposiciones no integran las 150 fotografías, la artista decide que, para la muestra en los municipios habitados por los familiares de las víctimas de desaparición forzada, las imágenes estén en su totalidad (ERIKA DIETTES, ARTISTA, HABLA DE SU OBRA RÍO ABAJO, 2010). Algunas exposiciones de Río Abajo se han realizado en espacios que convencionalmente están relacionados con la congregación de las personas alrededor de ritos vinculados a una creencia metafísica: los templos. En los templos generalmente se vincula la creencia de la existencia del espíritu más allá del cuerpo representado en la resurrección de Cristo. La creencia en Cristo se fundamenta en la existencia de un ser que ha vencido la muerte, una muerte dolorosa, trágica, muy común también en los cuerpos de los santos y de los mártires de la Iglesia. El cuerpo de Cristo que fue torturado no está en el sepulcro, no aparece, así como tampoco en la obra

\footnotetext{
2 Creado en 1981 por Ómar Rayo, pintor colombiano. El artista fue ganador de un premio en la Bienal de São Paulo, Brasil, razón por la cual el municipio de Roldanillo -del cual es originario, como reconocimiento, le donó un terreno para que creara un espacio con nuevas posibilidades para el arte en un territorio plagado por la violencia del narcotráfico. Según el portal web verdad Abierta, la organización narcoparamilitar Los Rastrojos patrullaban un área conocida como "triángulo invisible", que comprendía los municipios de El Dovio, Roldanillo y el corregimiento de Betania (ESTA TIERRA..., 2015).
} 
aparecen cuerpos. Las imágenes de la obra nos presentan, según Ileana Diéguez, “la estela corporal, objetual, puesta ante los ojos, del ser violentamente perdido" (DIEGUEZ, p. 7, 2019?).

Río Abajo está construida a partir de 26 fotografías de prendas de personas desaparecidas a causa del conflicto armado colombiano, que se presume están en ríos del Oriente Antioqueño ${ }^{3}$, Chocó ${ }^{4}$, Caquetá5 y Bogotá ${ }^{6}$, las imágenes fueron

\footnotetext{
${ }^{3}$ El Oriente Antioqueño conocido como el altiplano es una zona integrada por Rionegro y los municipios de Marinilla, El Santuario, El Retiro, Guarne, El Carmen de Viboral, La Ceja, San Vicente, La Unión, El Peñol, Cocorná, San Roque, San Luis, San Francisco, Sonsón, Granada, San Rafael, Guatapé, Nariño, San Carlos, Concepción, Argelia, Alejandría y Abejorral. En los anteriores lugares se desarrolla prácticamente la totalidad de la actividad industrial del departamento de Antioquia, convirtiéndose un territorio estratégico para la economía y el desarrollo, tanto del departamento como del interior del país, razón por la cual esta zona se ha convertido en un lugar disputado por los distintos actores armados. En los años 1980, las guerrillas ocuparon ese territorio, generando desplazamientos forzados; en 1997, Carlos Castaño irrumpió en el departamento de Antioquia por medio de una masacre en la vereda La Esperanza del municipio El Carmen de Viboral. El ingreso de los paramilitares en el departamento tuvo por objeto disputar y dominar los territorios de la guerrilla, logrando establecer el control sobre todo el Oriente Antioqueño. A partir de las masacres en San Rafael, San Luis y San Carlos, así como de los asesinatos selectivos, estos grupos instauraron su presencia en las zonas urbanas de los 23 municipios del oriente de Antioquia.
}

${ }^{4}$ Chocó es un departamento de Colombia ubicado en el noreste del país, limita al norte con el Océano Atlántico y Panamá, al noreste con Antioquia, al este con Risaralda, al oeste con el Océano Pacífico y al sur con el Valle del Cauca. Cuenta con un puerto marítimo en el Golfo de Urabá y otro en la Bahía Cupica, por lo cual este territorio ha sido una de las rutas más importantes para movilizar drogas hacia el exterior. Se ha considerado que Chocó es uno de los epicentros geográficos de la prolongación de la guerra en Colombia, debido a su riqueza minería ilegal, la explotación de oro y los cultivos ilícitos-, considerada un factor de disputa de los actores armados y la industria. Los actores armados han utilizado las masacres como medio para tener dominio territorial, una de ellas fue la masacre cometida por las Autodefensas Campesinas de Córdoba y Urabá (ACCU) el 20 de diciembre de 1996, en el municipio de Riosucio, para ese momento el Frente 57 de las Fuerzas Armadas Revolucionarios de Colombia (FARC) ocupaba el territorio, en el ataque paramilitar predominó el asesinato masivo de quienes se sospechaba colaboraban con la guerrilla. También se encuentra la masacre de Bojayá, ocurrida el 2 de mayo de 2002, en un enfrentamiento entre las Autodefensas Unidas de Colombia (AUC) y las FARC, los primeros usando como escudo humano a los pobladores y los segundos, agrediéndolos al lanzar una pipeta de gas en la iglesia, la detonación de la pipeta dejó 119 muertos y 30.000 desplazados.

${ }^{5}$ Caquetá es un departamento ubicado al sur de Colombia, limita al norte con Guaviare y Meta, al sur con Amazonas y Putumayo, al occidente con Cauca y Huila y al oriente con Vaupés. Históricamente, Caquetá ha sido fortín político y militar de la guerrilla de las FARC, en este lugar nace el Bloque Sur de este GAMIL. La zona es altamente influenciada por el narcotráfico, pues allí se ubica la mayor parte de los cultivos de coca, por ello, ha sido un territorio disputado entre diferentes actores armados y grupos ilegales, en consecuencia, el departamento se ha convertido en un escenario de tomas, secuestros, masacres y demás violaciones de derechos humanos.

${ }^{6}$ Bogotá es la capital del departamento de Cundinamarca y de la República de Colombia. A pesar de la mirada ingenua sobre el nulo impacto del conflicto armado en la capital del país, en la periferia de la ciudad se han gestado dinámicas propias de la violencia, pues en localidades como Ciudad Bolívar, Usaquén, Bosa, Usme o San Cristóbal se han evidenciado asesinatos selectivos o toques de queda, eso sin mencionar que en estos sectores arriban aquellas personas desplazadas de los lugares más apartados del país. En Bogotá han ocurrido 
tomadas entre los años 2007 y 2008 (ARTE..., 2016). La técnica de la obra es fotografía digital impresa sobre cristal. "En estas imágenes de gran formato impresas en vidrio se pueden apreciar las prendas sumergidas en agua: un agua transparente que las muestra en un estado aséptico" (ARTE..., 2016) (FIGURA 1).

Figura 1 - Río Abajo en Parroquia Nuestra Señora de las Nieves, Bogotá7.



Fuente: Diettes (2014).

Las imágenes (FIGURAS 2-4) que componen la obra Río Abajo son, en su mayoría, prendas de vestir, pero no todas: vemos un vestido rojo con flores azules de niña, un traje de gala de sargento de la Fuerza Armada, unos pantalones blancos.

acontecimientos que han agudizado el fenómeno de la violencia y del conflicto armado, entre ellos se encuentran el Bogotazo, la toma y retoma del Palacio de Justicia, los atentados de Pablo Escobar, el asesinato de candidatos presidenciales y los actuales asesinatos de líderes sociales, así como la denominada limpieza social.

Fotografía de Paula Alvarado, s. f. Disponible en: https://static1.squarespace.com/static/54918f84e4b0b437af2bbcf0/5493619ae4b064f2d342685 9/54936333e4b00173e536529b/1418945332545/rioabajo01.jpg?format=1500w. Acceso en: 15 sept. 2018 
Figuras 2-4 - Fotografías 1, 3, y 11 de la serie Río Abajo.
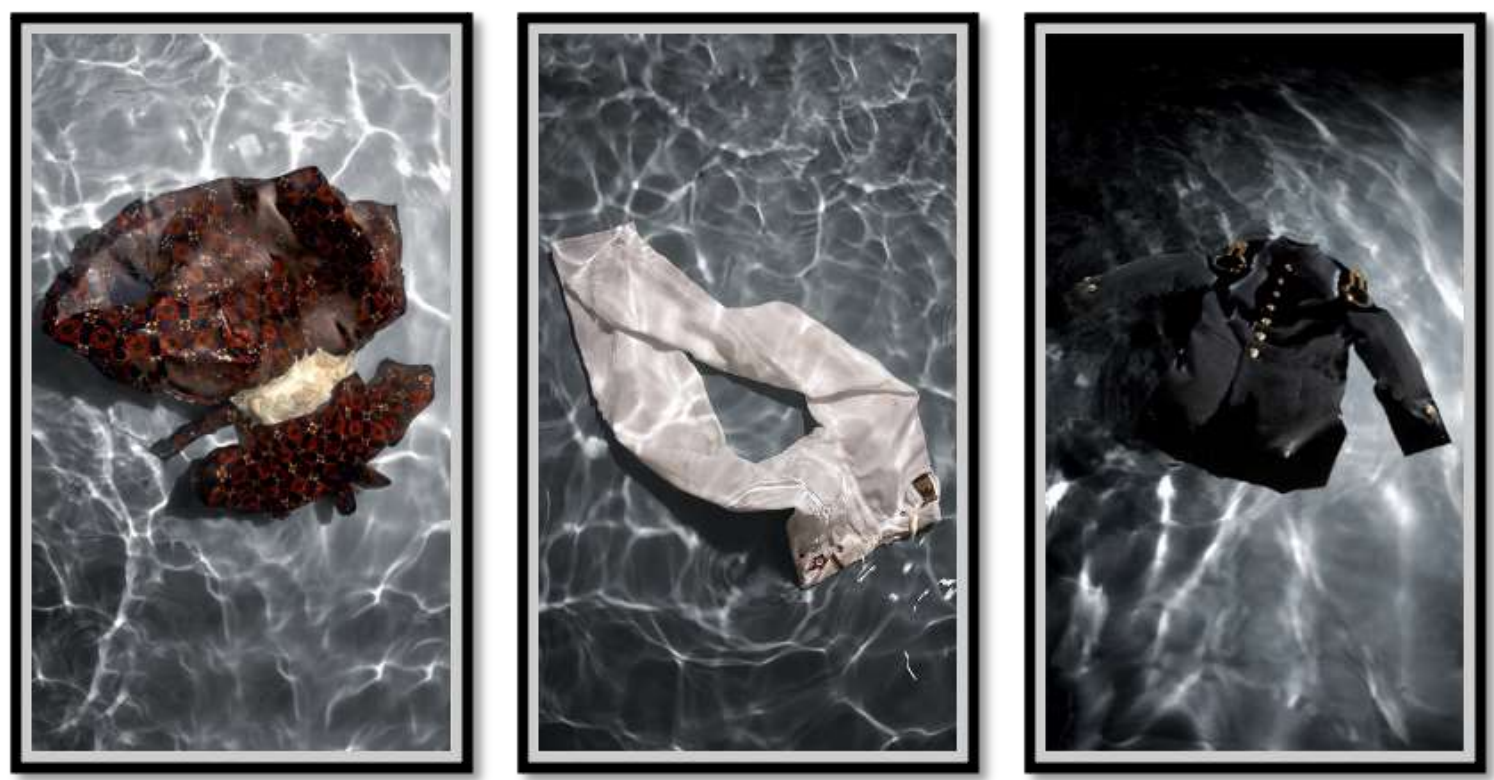

Fuente: Diettes (2014).

Diettes recuerda cómo inicia la tarea de recuperar las prendas:

Yo empiezo un recorrido muy grande por el país a través de diferentes asociaciones de víctimas y me entrevisto con las madres, particularmente las madres, pues también hay hermanos, esposas, familiares de personas desaparecidas; y les pido si me prestan un objeto que ellos guarden y allí se abre un universo de duelo impresionante. (NARRAR LA HISTORIA DE NUESTRO PAÍS CREO QUE ES UNA OBLIGACIÓN, 2014).

En una entrevista en Semana Rural, Diettes afirma que esboza Río Abajo en Bogotá entre 2005 y 2006, momento en el cual la madre del Mayor Julián Ernesto Guevara ${ }^{8}$ aparecía en diferentes vallas publicitarias pidiendo la entrega del cadáver de su hijo, pues sabía que había muerto en cautiverio (PUENTES, 2018). Ante esto, a la artista se le ocurrió hablar con Emperatriz de Guevara y pedirle que le prestara la ropa de su hijo para llevarla al estudio ${ }^{9}$ y buscar las

\footnotetext{
Julián Ernesto Guevara Castro fue un Capitán de la Policía de Colombia. Secuestrado el $1^{\circ}$ de noviembre de 1998 por la guerrilla de las FARC durante la toma de la ciudad de Mitú (Vaupés), murió en cautiverio el 28 de enero de 2006 en las selvas de Putumayo. Trascurrieron 4 años para que su madre recibiera el cuerpo y le diera sepultura. Fue ascendido al grado de Mayor de manera póstuma.

En entrevista personal con la artista en 2017, afirma que llegó a su estudio después de la conversación con la madre, colgó el uniforme en el primer piso del estudio y subió. Ella dormía en el segundo piso y bajaba a verlo. Duró días en esta dinámica, llorando sin saber qué hacer
} 
imágenes del proyecto, es así como la fotografía del uniforme de gala del Mayor sumergida en agua (FIGURA 4) es la primera imagen de la obra ${ }^{10}$, ese primer acercamiento a la prenda implicó determinar la temperatura del líquido en donde flotaba el traje y la calidad del agua

[...] después de tener estas primeras imágenes sentí la necesidad que el proyecto fuera transparente. A medida que me encontré con sus elementos entendí que lo que estaba fotografiando era el retrato de un fantasma. Y llegué a la idea de que las imágenes tenían que ser impresas sobre vidrio (CALLE, 2008).

Vemos de esta forma también un saco rojo de niño de colegio, un vestido de mujer rosado sin tirantas, unas gafas(FIGURAS 5-7):

Figuras 5-7. Fotografías 2, 4, y 6 de la serie Río Abajo.
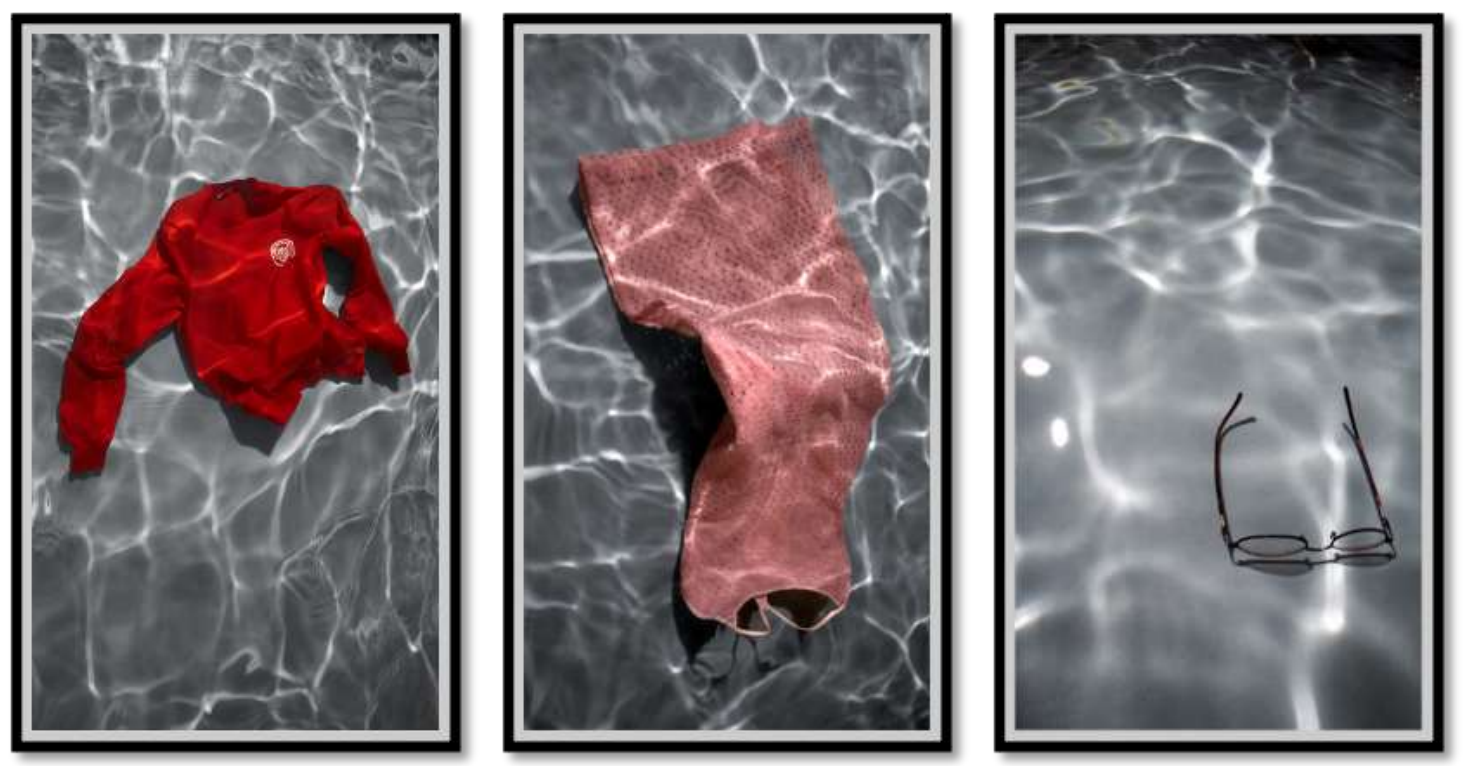

Fuente: Diettes (2014).

\footnotetext{
con la prenda. Después de repasar una y otra vez su conversación y escuchar la prenda, decidió sumergirla en agua.

- Llama la atención que sea el traje de gala del Mayor Guevara el que inicia la obra, puesto que en los casos de desaparición forzada se ha considerado que el Estado es uno de los actores armados que más incidencia ha tenido en este delito. En los años 1970, este crimen ingresó al país bajo la modalidad de "lucha contrainsurgente, y estuvo ligada a la tortura como medio para obtener confesiones del enemigo. Las desapariciones forzadas sucedieron, en ese entonces, en el marco de las detenciones sin orden judicial" (Grupo de Memoria Histórica, 2013, p. 59). Los informes Hasta Encontrarlos: el drama de la desaparición forzada en Colombia (2016), del Centro Nacional de Memoria Histórica, y iBasta Ya! Colombia: memorias de guerra y dignidad (2013), del Grupo de Memoria Histórica, señalan al Estado colombiano y a las Fuerzas Armadas como los principales responsables del delito de la desaparición forzada, en tanto, en alianza con grupos paramilitares y narcotraficantes, se perpetraron múltiples desapariciones que tenían por objetivo eliminar a los disidentes del modelo neoliberal instaurado en Colombia.
} 
Se podría pensar que, aunque Diettes busca representar la ausencia de los desaparecidos, los espectros capturados en sus fotografías son únicamente reconocidos por sus familiares, es decir, la identidad de los desaparecidos está encriptada, y en esa medida hay un blanqueamiento de la singularidad del hecho fáctico. Si bien es cierto, el espectador identifica la heterogeneidad de prendas, en tanto, diferencia cada pieza; el proceso de simbolización termina por achatar la subjetividad de cada fantasmagoría y la memoria política (individual) del pasado que irrumpe e interroga el presente. En ese sentido, el discurso de la obra peligra al forzar la unanimidad y homogenización de los testimonios, el consenso representado en la transparentación despolitiza la memoria (RICHARD, 2002, p. 188-190) y la identidad de los desaparecidos. En esa medida, el carácter de transparencia de la obra podría conducir a un consenso de las voces heterogéneas, y por ello, actuar como un acto de compulsión al olvido, en tanto, camufla las cicatrices y mutilaciones de los vencidos tras la simbolización de la imagen, una imagen que no contiene rastros de nombre/identidad (RICHARD, 2002, p. 190). Por el contrario, instaura sombras, fantasmas que de alguna forma silencian los acontecimientos pasados en la esfera pública, en tanto a través de la imagen es imposible diferenciar los tipos de violencias de las que fueron víctimas, los móviles, actores, circunstancias, tiempos o espacios.

Sin embargo, frente a lo anterior, habría que enfatizar que lejos de situarse en el olvido público trabajado por Huyssen, ni la obra ni la artista radicaliza una posición política binomial característica de la historia política de Occidente, sino que, al contrario, la fantasmagoría le permite, como dispositivo estético, irrumpir en la dicotomía amigo/enemigo que ha sido utilizada para fines al servicio de la prolongación de la guerra.

Desde la crítica se debe señalar algo que deviene más de la fotografía como documento en relación con el carácter positivista que adquirió posterior a su creación como confirmación de que algo existe, es decir, este elemento pasa a ser probatorio igual que en su momento, la historia. 
Se debe considerar que un documento es verdadero y falso a la vez, es decir, es una traducción que nunca podrá ser lo que sucedió, porque el hecho real siempre será extralingüístico, este hecho narrado por una subjetividad inmersa en determinado contexto social que se enuncia desde un lugar específico. Habría entonces que diferenciar siempre el carácter de monumento como algo políticamente instituido a través de los ejes de poder, de esta misma forma en la foto, pues al igual que la historia, la foto puede contar una verdad hegemónica, una verdad construida a partir de unos intereses políticos y económicos. La producción de los documentos-monumentos son productos de un centro de poder por lo que el monumento será un disfraz de apariencia engañosa, y así la cosas, la tarea está en deconstruir o desestructurar desde diferentes perspectivas: cultural, política, social y jurídica, las condiciones de producción sobre las cuales estos documentos-monumentos fueron construidos, para evidenciar su carácter de instrumento de poder.

Al respecto, Kracauer (2010, p. 94-104) establece una analogía entre fotografía e historia -relacionada con la verdad objetiva- en donde hay un espacio-tiempo que no se compone únicamente de una imagen, como sucede en la fotografía, sino que es un trozo de un espacio-tiempo, un trozo muy pequeño, un punto de focalización, pero el espacio-tiempo está compuesto por una cantidad de capas verticales e hilos horizontales que no necesariamente se influirán mutuamente, o sí, pero no necesariamente.

Kracauer, frente a los supuestos positivistas que han ido permeando la historia, propone la construcción del relato polifónico, que deviene de problematizar la focalización de la narración misma, poniendo en evidencia los diferentes puntos de vista sobre un hecho teniendo en cuenta la lejanía o la proximidad y toda la discusión sobre el problema de la objetividad en el sujeto que la enuncia. 
Figuras 8-10. Fotografías 5, 8, y 9 de la serie Río Abajo.
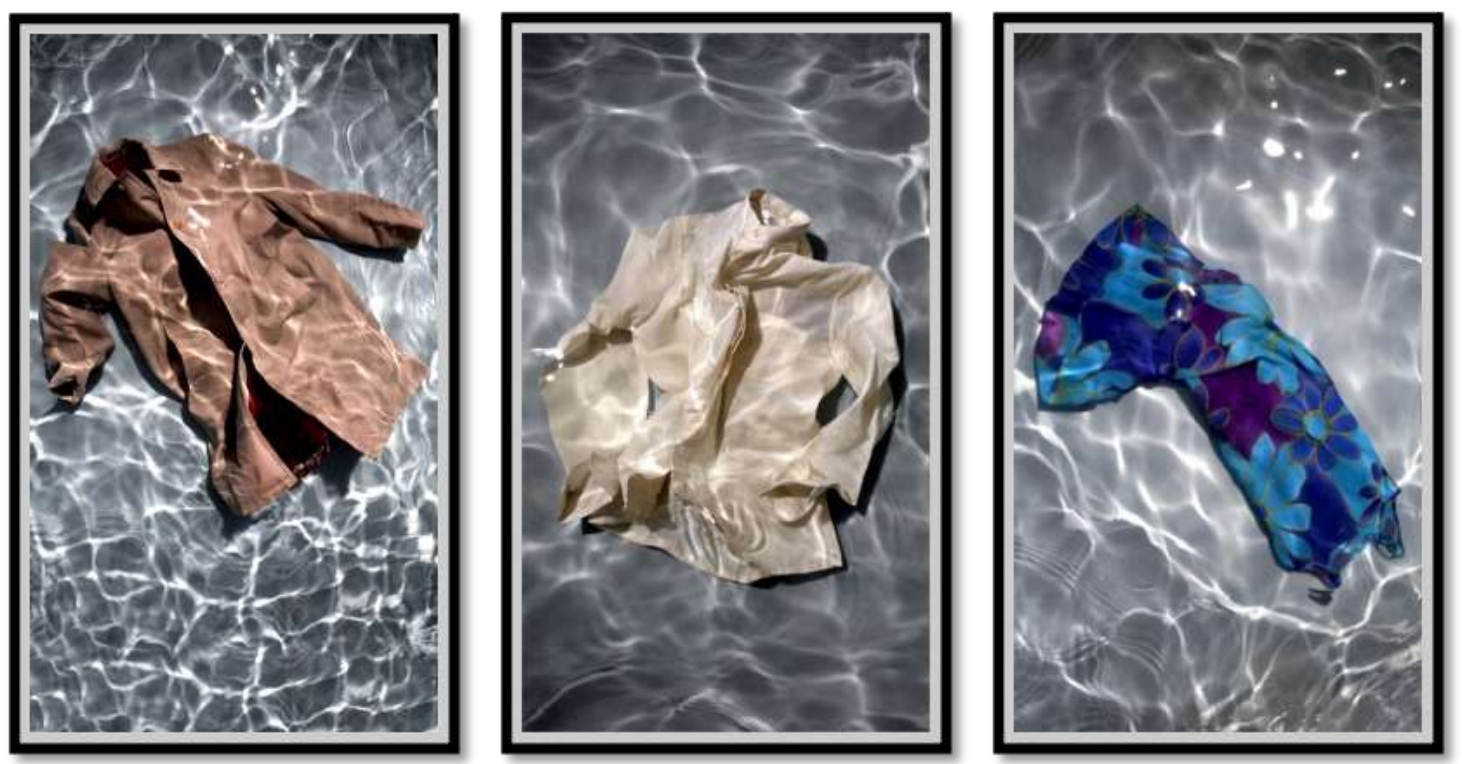

Fuente: Diettes (2014).

En Río Abajo vemos imágenes, pero, ¿qué vemos en esas imágenes? Vemos fotografías de elementos de uso cotidiano para vestir -cubrir el cuerpoflotando en agua (FIGURAS 8-10). Vemos ropa, gafas, maletas, zapatos, gorras, cobijas. Lo que se está mostrando son fragmentos de la vida cotidiana focalizados desde un primer lugar de enunciación, poniendo en tensión la narración del mundo histórico y del mundo de la vida: las gafas para ver bien, la gabardina para la lluvia, la cartera de la mujer, los zapatos del hombre o el vestido de la niña, a través de los cuales se instaura una reflexión sobre esas prendas, a partir de la contradicción misma entre la fotografía - de prendas de una persona que existe- y la historia - de una persona que no existe más que en el lenguaje ${ }^{11}$, en el recuerdo ${ }^{12}$, de forma tangencial ${ }^{13}$.

Las fotografías que componen la obra Río Abajo, al centrar la focalización en las prendas usadas en el uso cotidiano, como lo propone Kracauer ${ }^{14}$, amplían

\footnotetext{
1 Desde un punto de vista heideggeriano.

2 Desde el punto de vista de los familiares.

3 Desde un punto de vista indicial.

${ }^{14}$ Kracauer propone al yo del que investiga el pasado como un yo que no es fijo, sino un yo móvil que se alimenta todo el tiempo de un ir y venir, un yo en construcción, un yo gerundio: un no soy si no un estoy siendo, un devenir, un fluido, un viajero a través del tiempo, a través de la subjetividad, un viajero a través de su propio yo, ese yo que se encuentra en de-construcción constante, relacionado con las focalizaciones, lo que está planteando es la movilidad y el fluir
} 
el fragmento, muestran a partir de ese fragmento prueba de vida, la paradoja muerte-vida de diferentes personas, configurando un tiempo-espacio de forma heterogénea por distintos sucesos fragmentados, vidas fragmentadas, no necesariamente en orden cronológico, pero si con una distribución en el tiempo, el fenómeno de la desaparición. El fenómeno hace coexistir en el pasadopresente-futuro la muerte-vida, así como lo hace la obra. La creación de ese tiempo-espacio colectivo suspendido en agua es la presentación de una focalización en primer grado de diferentes fragmentos de cotidianidades que confluyen en la creación de ese universo tan tenebroso como real, que se compone del punto de encuentro de vidas particulares -universo como pluralidad o pluralismo- sobre un mismo hecho: desaparecer.

Sin embargo, la obra no se reduce a ser un elemento probatorio de la historia de un crimen tan polémico en el país, "se trata de mirar las imágenes entonces, sin pretender agotar en ellas la verdad de lo ocurrido, sino para abrir con ellas el cierre que todo pasado impone sobre el tiempo político e indeterminado del presente" (VILLALOBOS-RUMINOTT, 2016, p. 185), a través de la focalización la obra sitúa en la esfera social aquella memoria inquietante de forma heterogénea, atemporal, de una realidad siniestra frente a un hecho que aún no ha sido aceptado, en medio de un proceso de justicia transicional, lo cual abre las posibilidades del olvido en un contexto político que sistemáticamente ha ocultado las estrategias de desaparición.

¿En qué agua flota la ropa que vemos en la imagen (FIGURAS 11-13)? No parece agua de río, ni de mar, es un agua limpia, lumínica, que contiene una sola prenda. La imagen de la prenda evoca su uso, evoca a las personas que la usan, pero no están presentes. ¿Qué causa la conmoción? Que efectivamente no hay personas. El vestido de niña, el short de joven, la camisa de hombre, el vestido de mujer, las gafas, los zapatos, el abrigo, el vestido de tirantas, la maleta: todo se refiere a las personas que no están, a los ausentes. En las fotos no aparece ningún sujeto, ningún cuerpo, pero el movimiento dado a la ropa evoca su uso, el cuerpo aparece en su ausencia, cual elemento que ha dejado su impresión en el molde, el cuerpo aparece en su negación. La forma de presentación de los 
cuerpos en la obra Diettes es negativa, a través de los elementos que recubrían un cuerpo que no está, cuerpo que no tiene una materialidad.

Figuras 11-13. Fotografías 7, 14, y 17 de la serie Río Abajo.
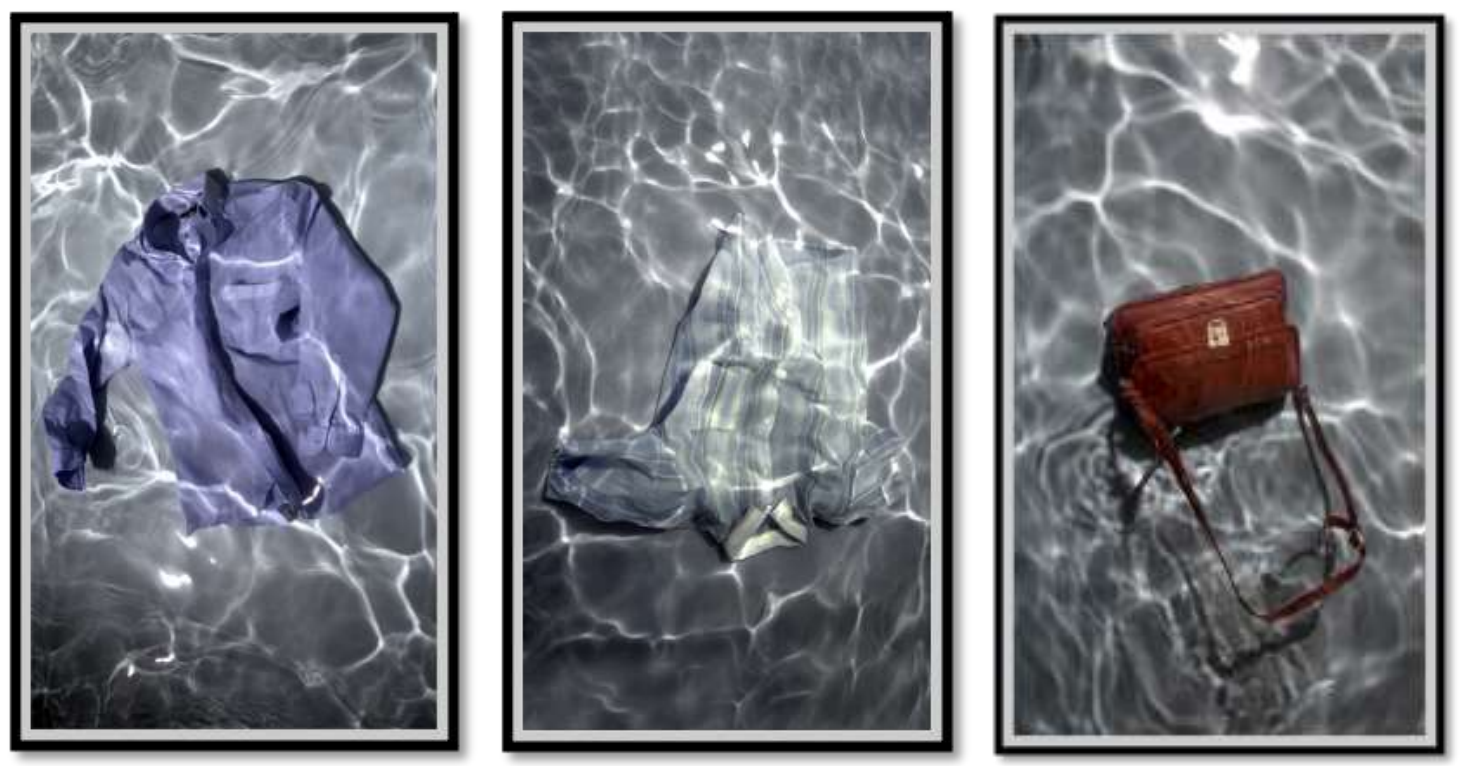

Fuente: Diettes (2014).

Esta ropa usada centra la mirada sobre sí misma, sobre su uso, sobre el uso que se le dio otrora y que en la actualidad no se le da por el fenómeno de la desaparición. Lo que muestra es el valor de uso suspendido y el valor de cambio eliminado, descentrando la imagen de la producción capitalista y su cúmulo de mercancías de carácter bicéfalo. Prenda de ninguna forma intercambiable debido a sus características particulares, abstrayéndose ella misma de la lógica mercantil ${ }^{15}$, no hay forma de que tenga valor de cambio en tanto que el valor de una mercancía lo constituye, no el trabajo concreto que la ha producido, sino el trabajo abstracto que permite intercambiar mercancías diferentes.

La obra no es entendida dentro de la lógica del divertimento, creada como un producto (ADORNO, 2009, p. 39), por el contrario, el espectador experimenta la resistencia de un discurso oculto que no sirve a su distracción, sino que por el

\footnotetext{
5 De acuerdo con Adorno, aunque en el ámbito mercantil el arte parece estar excluido del valor de intercambio, esto es una apariencia, en tanto los medios culturales tienen valor de cambio, pertenecen a la lógica de la mercancía en tanto se fabrican para el mercado y se atienen a él. Sin embargo, Rio abajo no está producida para el mercado, su valor de consumo, propio de los bienes culturales, no ha sido asumido por el valor de cambio, en tanto no se ha constituido como un objeto de placer y por lo tanto es una mercancía sin funcionalidad.
} 
contrario lo devuelve a la vida misma en la catástrofe alejándolo del "engaño que consiste en la oferta de lo siempre igual"16, una limitación de la oferta en términos morales, estéticos, éticos o sociales, marcados por una imposibilidad de una oposición fuera del marco de visibilidad, del marco enunciativo. Frente a esto, Río Abajo mantiene el carácter asceta - dialéctico- del arte planteado por Adorno (2009, p. 19), exclusión de lo placentero listo para ser consumido: "todo arte fácil y agradable, se ha vuelto aparente y falaz [...] Quien se deleite con el arte será un preservador de la cultura”. Y, en este sentido, un preservador de los regímenes, del sistema impuesto para la preservación y como reflejo tanto de las clases como de los medios de producción.

Adorno y Horkheimer parten de la idea que el arte tiene una relación "derivada con la realidad social, en el sentido en que es parte de esta y no puede entenderse al margen de ella” (DÍAZ, 2008, p. 52), sin embargo, esta relación que plantean es una relación negativa, ya que "el arte, con su propia legalidad, se opone a las reglas utilitarias de la sociedad" (DÍAZ, 2008, p. 52). Es decir, en una sociedad capitalista el arte debe funcionar como resistencia a la instrumentalización del producto. La negatividad dialéctica como forma de resistencia es, en efecto, la posición que asume Adorno como única posibilidad de escapar a la reificación del pensamiento por la industria cultural, la cual construye desde la concepción de crítica, conocida como dialéctica negativa:

La crítica no es una pasión de la cabeza sino la cabeza de la pasión. No es el bisturí anatómico, sino un arma. Su objeto es el enemigo, al que no trata de refutar, sino de destruir. La crítica no se comporta como un fin en sí, sino simplemente como un medio para la emancipación. Su sentimiento esencial es el de la indignación, su tarea esencial la denuncia. La crítica no concede ni un sólo momento de ilusión o resignación. Hay que hacer la opresión real más opresiva, despertando la conciencia, haciendo la infamia más infame, dándola a conocer públicamente. La crítica debe obligar a las relaciones sociales anquilosadas a bailar, cantándoles su propia melodía. (MARX, 2014, p. 13)

\footnotetext{
16 De acuerdo con Theodor Adorno y Max Horkheimer (1994, p. 168), "el esquematismo del procedimiento se manifiesta en que, finalmente, los productos mecánicamente diferenciados se revelan como lo mismo. [...] Lo que los conocedores discuten como méritos o desventajas sirve sólo para mantener la apariencia de competencia y de posibilidad de elección". Por lo tanto, vivifica el triunfo del capital invertido, en tanto que el consumidor no tiene nada por clasificar ya que no hay nada que no haya sido ya anticipado en el esquematismo de la producción.
} 
La dialéctica negativa tendría que utilizar los medios de los cuales disponemos para deconstruir los conceptos implantados de forma masiva -pero no únicamente- cuyas lógicas no obedezcan ni al sistema político ni al sistema económico implementado, y que sea un mecanismo a través del cual se evidencien los determinismos a los cuales la sociedad está advocada, como otras formas de ser, hacer y estar en el mundo.

En ese sentido, la relación dialéctica de Río Abajo es energía productiva, puesto que una y otra vez se evoca la imagen de la contradicción para darle duración a la obra. La contradicción no es de sensibilidad, ni de subjetividad que vacila entre forma y expresión. Es una contradicción para el conocimiento, como correctivo a la sensibilidad. La "contradicción [se da] entre la fuerza del artista y la fuerza de la realidad, con la que el artista se encuentra” (ADORNO, 2003, p. 52). Es decir, es una contradicción entre sujeto y objeto - no para establecer una compensación-, de la forma en la que "ambos se engendran de modo recíproco tal como ellos mismos están engendrados: históricamente" (ADORNO, 2003, p. 53). De esta forma, la obra a través de estas mercancías sin utilidad irrumpe en el tiempo historiográfico, homogéneo y acontece por un momento como la contradicción de lo dicotómico dado en la identificación subjetiva desde la sensibilidad del otro.

Figuras 14-16. Fotografías 13, 16, y 21 de la serie Río Abajo.
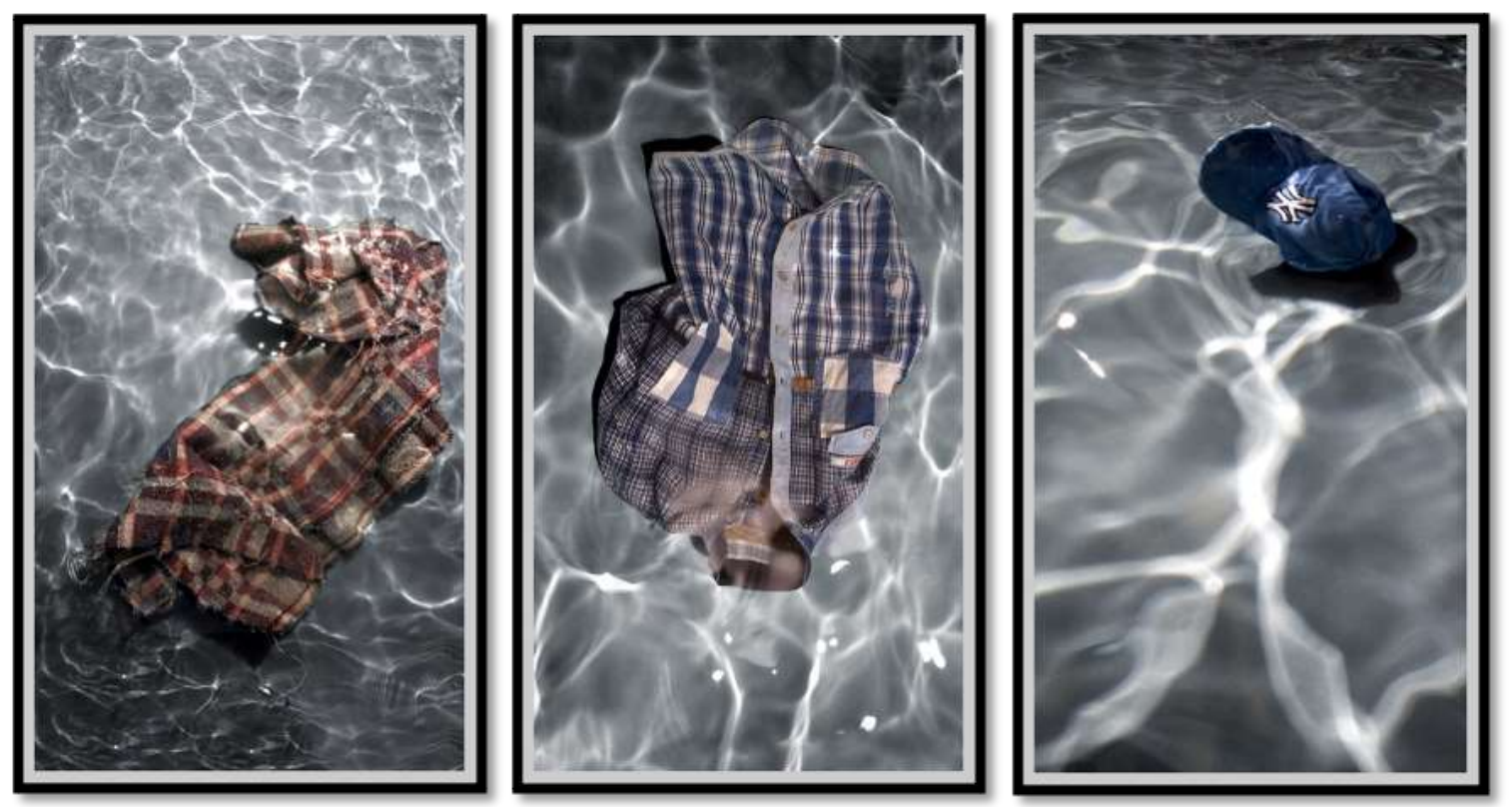

Fuente: Diettes (2014). 
En la obra de Diettes (FIGURAS 14-16), el vacío está sugerido por ese algo que falta: la presencia del cuerpo. La obra nos sumerge en un vacío de tipo visual, en un lugar donde queda una leve imagen de alguien que es/fue. El vacío es necesario para el movimiento, para la relación. Didi-Huberman (2008), en Cuando las imágenes toman posición, relaciona la forma con el contenido en la obra de Brecht, postulando que a partir de la deconstrucción se da la relación de las redes. Para esto, Didi-Huberman parte de la diferenciación entre lo dramático ${ }^{17}$ y lo épico ${ }^{18}$ en Brecht, indicando que el quiebre entre la narración de los acontecimientos lineales y los acontecimientos curvos revelan las distancias del acontecimiento histórico. En lo épico, existe una "red de relaciones que se esconde tras los acontecimientos [ya que] ocurra lo que ocurra, siempre hay otra realidad detrás de la que se describe" (DIDI-HUBERMAN, 2008, p. 70) que exige un observador que multiplique sus puntos de vista, acción que lo ubica en un terreno móvil. Lo épico, a diferencia de la forma dramática en donde se suceden los acontecimientos de forma lineal, revela las discontinuidades que conllevan los sucesos históricos. El teatro épico, por lo tanto, no reproduce el estado de las cosas, sino produce un mecanismo estético por medio del cual descubre su estado a través de la interrupción de la acción y por lo tanto, la creación de las discontinuidades y el recorte de episodios debido al encuadre. A esta forma peculiar de "dys-poner" las cosas se llamará "Montaje de la complejidad" (DIDIHUBERMAN, 2008, p. 74), en donde el distanciamiento será la "toma de posición por excelencia" (DIDI-HUBERMAN, 2008, p. 75). Este montaje de la complejidad es también llamado por Didi-Huberman el montaje de la historicidad inmanente, "cuyos elementos, sacados de lo real, inducen por su puesta formal un efecto de conocimiento nuevo que no se haya ni en la intemporal ficción, ni en la factualidad cronológica de los hechos de la actualidad" (DIDI-HUBERMAN, 2008, p. 73).

El efecto del distanciamiento es una crítica a la ilusión, puesto que en el gesto de mostrar está la intención de distanciar, es decir, de mostrar "al

\footnotetext{
17 Lo dramático en Brecht, de acuerdo con Didi-Huberman, está relacionado con los episodios de la historia.

18 Lo épico en Brecht, de acuerdo con Didi-Huberman, tiene sentido en cuanto a forma de observación histórica, que se logra a través de la observación de las relaciones de los episodios en la técnica del montaje.
} 
espectador que lo que ve no es más que un aspecto lacunario y no la cosa entera, la cosa misma que la imagen representa" (DIDI-HUBERMAN, 2008, p. 76), mostrar la imagen como un asunto de conocimiento implica una crítica a la identificación que no permitiría tomar la distancia necesaria para su observación, por lo que mostrar será "adjuntar visual y temporalmente las diferencias" (DIDI-HUBERMAN, 2008, p. 78).

Lo real en la obra es mostrado en su calidad de fragmento, como realidades separadas y desde diferentes enfoques reagrupadas, no unificadas. Las imágenes de Diettes se vuelven poderosas desde la negatividad en la medida que son enunciativas de verdad fractal, indicial, imágenes metáfora de soledad, represión, dolor, falsedad, desaparición, testimonio en sí mismas del conflicto del país.

En la obra, vemos el caos compuesto, la ruptura, el instante apremiante, la coherencia agrietada, la distancia de los acontecimientos. El observador debe ser activo, debe tener aguzada la mirada, debe componer lo descompuesto, encontrar aquella red que teje las relaciones entre lo no lógico, lo no narrativo, lo no causal, en la dialéctica de las formas. El efecto del distanciamiento en el montaje de la obra crea los intervalos en donde antes se veía unidad, la imagen se revela como un indicio de una verdad mucho más grande que llama a engullir el orden político establecido, la función social del arte devela su relación contemporánea con la historia, en donde el artista "debe combatir conceptos y sustituirlos con otros" (DIDI-HUBERMAN, 2008, p. 105). La historia y el arte se presentan como universos inseparables, en donde "el artista [...] fabrica heterogeneidades para dys-poner la verdad en un orden que no es precisamente el orden de las razones, sino el de las "correspondencias'” (DIDI-HUBERMAN, 2008, p. 108).

Esa unidad, puesta lejos en la obra y traída a primer plano de la complejidad, y su naturaleza disociada es llamada "un arte de la historización: un arte que rompe la continuidad de las relaciones, extrae de ellas diferencias y, al componer esas diferencias juntas, restituye el valor esencialmente crítico de toda historicidad" (DIDI-HUBERMAN, 2008, p. 78). 
La obra propone una operación de conocimiento crítico sobre la historia a través de un dispositivo estético: "la finalidad del efecto distanciador consistía en procurar al espectador una actitud analítica y crítica frente al proceso representado" (DIDI-HUBERMAN, 2008, p. 79). Lo político está en la elaboración estética, por lo tanto, en la posición que asume el artista. Lo político está en mostrar que se está mostrando lo que se está mostrando:

[...] la refundación de lo político deberá pasar por las refundaciones estéticas y analíticas que se implican en las tres ecologías del ambiente, el socius y la psique. [...] no se puede concebir una recomposición subjetiva del socius, correlativa de una singularización de la subjetividad, sin una nueva manera de concebir la democracia política y económica, en el respeto de las diferencias culturales y sin múltiples revoluciones moleculares. (GUATTARI, 1996, p. 34)

Diettes muestra cada fotografía distanciada de la otra en el sentido en que pone lejos y requiere aguzar la mirada, "el arte no ha de presentar las cosas ni como evidentes (hallando aprobación sentimental), ni como incomprensibles, sino como comprensibles, pero todavía no comprendidas" (DIDI-HUBERMAN, 2008, p. 81).

El efecto de extrañeza (DIDI-HUBERMAN, 2008, p. 141) durante la experiencia de la obra arroja al espectador a la sensación de duda sobre la realidad que se contrapone a su mismo reconocimiento, la forma de disponer las fotografías en el acto del montaje permite la visualización de unas imágenes que redispone la forma en la que el espectador ve el mundo. Se empieza a tejer una "red de relaciones como una extensión virtual que pide al observador [...] multiplicar sus puntos de vista”. Las relaciones se tejen entre las prendas y las personas que no están, entre las prendas y los familiares de la persona dueña de las prendas, entre las prendas y las personas que las miran, entre las prendas y las otras prendas de la obra y entre las prendas y las posibles prendas que no están en la obra, pero también, ante todo, la obra propone la relación de las prendas con otras prendas multiplicadas en una duración, pero contraídas virtualmente en el instante en donde todas flotan, un sentimiento de extrañeza acontece al ver estas imágenes -que logramos identificar como múltiples supra-, como unas gafas, un bolso y un vestido estén flotando en agua. "El 
montaje instaura una toma de posición - de cada imagen respecto las otras, de todas las imágenes respecto a la historia-" (DIDI-HUBERMAN, 2008, p. 141).

Figuras 17-19 - Fotografía 26, 23, y 22 de la serie Río Abajo.


Fuente: Diettes (2014).

Las imágenes de la obra de Diettes (FIGURAS 17-19) son constituyentes de recuerdos individuales que habitan las memorias de las personas que las guardan, pero también de los recuerdos de un país entero sobre sus desaparecidos. Sin embargo, si la obra de Diettes se moviera sólo en el espacio testimonial, en donde se visibilizan las memorias heterogéneas de las voces que no han sido escuchadas oficialmente en el pasado de forma reivindicatoria, vinculando en la historia la memoria como proceso contrahegemónico, las imágenes tomarían posición en el mismo espacio convencional dado por la política a través de la identificación, y por lo tanto la obra sería entonces la ilustración de la barbarie, cumpliendo una función pedagógica y politizante al hacer visible lo invisible.

Por el contrario, la obra se aleja del problema maniqueo de poner versiones binomiales en pugna, por ello la trasparencia o fantasmagoría se presenta como dispositivo estético, en donde propone la ruptura de los vínculos lógiconarrativos y de los sensorio-motores, como lógica narrativa que organiza los 
recuerdos ya siempre en la competencia por el poder. La obra no se sustenta ante el esquema de causa-consecuencia o acción-reacción, no hay una historia que contar ni una ideología que implementar, hay unos fragmentos indiciales que mostrar en provecho de la sensación óptica

[...] las políticas del registro [...] no puede remitirse a la lógica de la representación, de la prueba o del testimonio. Y esto sería fundamental para contrarrestar el uso exagerado de la testimonialidad como prueba, que sin advertir la condición fragmentaria y decadente de la fotografía (o del mismo lenguaje averiado del sobreviviente), se apresura en funcionalizarla y sobrecodificarla desde una identificación empática con las víctimas y sus sufrimientos ${ }^{19}$. (VILLALOBOS-RUMINOTT, 2016, p. 8)

La memoria no intencional despertada por la intervención de Diettes no restituye ni recupera un pasado en un tiempo de reconciliación y consagración (un tiempo marcado heliopolíticamente), sino que muestra el pasaje sucio de la historia. La fotografía no promete ni consagra, no monumentaliza ni idealiza, como la mercancía, sino que lleva el desastre al corazón de la mercancía y su tiempo, es decir, desactiva el fetichismo de la mercancía mostrando su reverso bruto, material y sucio. Diettes no fetichiza, sino que trabaja con los detritus de la historia, abriendo la pregunta por los restos y los desperdicios.

Río Abajo realiza el señalamiento de un pasado manipulado que no ha sido esclarecido y mucho menos divulgado, pues "somos víctimas de un pasado que no hemos querido mirar atrás, por temor a quedarnos paralizados" (ARCOSPALMA, 2010, p. 3), la obra de Diettes al traer al presente los acontecimientos pretéritos redime la memoria de los ausentes. Finalmente, el único vehículo por medio del cual las generaciones vivas tienen actualizado el recuerdo de los vencidos es la memoria, ahora bien, ese hacer memoria es un acto político en una sociedad que se ha desangrado paulatinamente.

\footnotetext{
19 Sergio Villalobos-Ruminott (2016, p. 8) precisa: "sería esa identificación empática y afectiva la que marcaría, por ejemplo, los usos del testimonio en los estudios latinoamericanos recientes, como si el horror de la historia acontecida pudiera traducirse, sin pérdida, a la lógica de la significación. Ese es el problema fundamental del testimonialismo contemporáneo: leer en la desgarrada congruencia del entre lenguaje y experiencia, las claves para una política de la recuperación y del reconocimiento”.
} 
En ese sentido, Río Abajo pone de manifiesto la subordinación y la condena a la que ha sido sometida no solo la memoria, sino también la vida al servicio del exceso de la historia - desde la perspectiva positivista-, en ese sentido, la intervención artística de Erika Diettes emerge en medio del conocimiento ahistórico del fenómeno de la desaparición forzada, cuestionando críticamente el tiempo histórico en términos de un horizonte de sentido, es decir, ante el olvido de nuestros desaparecidos la obra de Diettes se instaura en un lenguaje capaz de resignificar su recuerdo desde el presente y hacia el futuro, de ahí que las 26 fotografías sean el medio por el cual se plantea una historia útil para la vida, en términos de la revisión, actualización y reescritura del pasado, para comprender el presente y potenciar el futuro.

En Colombia, necesitamos un arte despojado de la lógica binomial amigo/enemigo, izquierda/derecha impuesta desde el arcaico discurso político, que haga volar por los cielos la enraizada regulación comunicacional en donde se presenta la violencia de forma estetizada o se utiliza la politización del arte para el movimiento de las masas que se inserta en la misma lógica destructiva estatal, unas imágenes que planteen una nueva forma de confrontar al pasado, una forma de enfrentar a la memoria, a la historia, a la propia vida.

La potencia de Río Abajo se funda en la posibilidad de generar un espacio de reflexión donde se produce un campo de intervención simbólico complejo y significativo. Esta obra se distancia de un posicionamiento político de tipo partisano, para profundizar en la experiencia íntima de la pérdida, en especial en sus dinámicas de temporalidad truncada en la que el pasado se amalgama en el presente con una fuerza demoledora que confronta las lógicas de la desaparición. En esta obra, el duelo no se evade, ni la pérdida es compensada o reparada, pues es en la crudeza de la ropa de los desaparecidos que flota en un medio prístino y traslúcido donde emana la pregunta sobre los cuerpos que han sido arrogados como basura para no ser encontrados. Estas fotografías no son pues una respuesta satisfactoria que convierta en arte el sufrimiento (estetización del dolor); constituyen, a fin de cuentas, la pregunta inquietante sobre ese lugar inasible al que van a parar los cuerpos, son también la pregunta sobre esos perpetradores invisibles que los arrogan al río impunemente. 


\section{Referencias}

ADORNO, Theodor. Filosofía de la nueva música. Trad. de Alfredo Brotons Muñoz. Madrid: Editorial Akal, 2003.

ADORNO, Theodor. Disonancias: introducción a la sociología de la música. Trad. de Gabriel Menéndez. Madrid: Editorial Akal, 2009.

ARCOS-PALMA, Ricardo. Río Abajo: de Erika Diettes. [S.l.: static 1], 2010. p. 1-11. Disponible en:

https://static1.squarespace.com/static/54918f84e4b0b437af2bbcfo/t/54937b34e 4b011bd56209fc8/1418951476212/rioabajoRAP.pdf. Acceso en: 30 ago. 2018.

ARTE Y DOLOR, 'RÍO ABAJO'. Revista Semana, [S.l.], 5 feb. 2016. Disponible en: http://www.semana.com/nacion/seguridad/galeria/arte-dolor-rio-abajo/1389303. Acceso en: 20 abr. 2017.

CALLE, Juan. Erika Diettes: Río Abajo. In: TERTULIAS FOTOGRÁFICAS. [S.l.], 7 nov. 2008. Disponible en: http://tertuliasfotograficas.blogspot.com/2008/11/erikadiettes-ro-abajo.html. Acceso en: 14 feb. 2017.

DÍAZ, Ariane. Huellas de las vanguardias. In: VEDDA, Miguel (comp.).

Constelaciones dialécticas: tentativas sobre Walter Benjamin. Buenos Aires: Herramienta, 2008. p. 45-57.

DIDI-HUBERMAN, Georges. Cuando las imágenes toman posición. trad. de Inés Bértolo. Madrid: Antonio Machado Libros, 2008.

DIÉGUEZ, Ileana. Cuerpos residuales prácticas de duelo. "Cuerpos residuales, prácticas de duelo". [S.l., 2019?]. Disponible en:

https://static1.squarespace.com/static/54918f84e4b0b437af2bbcfo/t/54937b58e 4b0b8156da021ce/1418951512584/cuerposResidualesID.pdf. Acceso en: 20 sept. 2019.

DIETTES, Erika. Río Abajo. [S.l., 2017?]. Disponible en:

http://www.erikadiettes.com/rioabajo/. Acceso en: 15 jul. 2017.

ESTA TIERRA ES MÍA. Verdad Abierta. [S.l.], 7 sept. 2015. Disponible en: https://verdadabierta.com/esta-tierra-es-mia-1/. Acceso en: 16 feb. 2019.

ERIKA DIETTES, ARTISTA, HABLA DE SU OBRA RIOO ABAJO. Entrevistas W. [S.l.: Wradio], 4 feb. 2010. Disponible en:

http://www.wradio.com.co/escucha/archivo_de_audio/erika-dietes-artistahabla-de-su-obra-rio-abajo/20100204/oir/948750.aspx. Acceso en: 10 oct. 2017.

GRUPO DE MEMORIA HISTÓRICA. iBasta ya! Memorias de guerra y dignidad. Bogotá: Imprenta Nacional, 2013. 431 p.

GUATTARI, Félix. Caosmosis. Barcelona: Editorial Manantial, 1996. 
HORKHEIMER, Max; ADORNO, Theodor. Dialéctica de la Ilustración. Trad. de Juan José Sánchez. Madrid: Editorial Trotta, 1994.

KRACAUER, Siegfried. Historia: las últimas cosas antes de las últimas. Buenos Aires: Las cuarenta, 2010.

MARX, Karl. Introducción a la crítica de la filosofía del derecho de Hegel. España: Editorial Pre-Textos, 2014.

'NARRAR LA HISTORIA DE NUESTRO PAÍS CREO QUE ES UNA OBLIGACIÓN': Erika Diettes. Blu Radio, [S.l.: Blu Radio], 2 nov. 2014. Disponible en:

http://www.bluradio.com/81330/narrar-la-historia-de-nuestro-pais-creo-quees-una-obligacion-erika-diettes. Acceso en: 7 nov. 2018.

PUENTES RAMOS, José. 'En el dolor es donde somos iguales', una charla con la artista Erika Diettes. Semana Rural, [S.l.], 27 ago. 2018. Disponible en:

https://semanarural.com/web/articulo/entrevista-a-erika-diettes-sobre-suobra-relicarios/615. Acceso en: 7 nov. 2018.

RICHARD, Nelly. La crítica de la memoria. Cuadernos De Literatura, [S.l.], v. 8, n. 15, p. 187-93, 2002. Disponible en:

https://revistas.javeriana.edu.co/index.php/cualit/article/view/8000. Acceso en: 26 feb. 2019.

VILLALOBOS-RUMINOTT, Sergio. Heterografías de la violencia: historia, nihilismo, destrucción. Avellaneda: Ediciones La Cebra, 2016.

Universidade do Estado de Santa Catarina - UDESC

Programa de Pós-Graduação em História - PPGH

Revista Tempo e Argumento

Número Especial - 2021

tempoeargumento.faed@udesc.br 